\title{
Grammar teaching in Portugal
}

\author{
Ana Luísa Costa \\ Polytechnic Institute of Setúbal
}

Sónia Valente Rodrigues

University of Oporto

(Text received July 25 2019; accepted July 25 2019)

DOI: https://doi.org/10.5565/rev/jt13.809

\begin{abstract}
Although some studies evidenced a divide between the practices and the curricular guidelines for first language teaching, in the Portuguese curriculum, there was always some place for grammar teaching. The debate focuses on the questions "why teach grammar?", "what to teach?" and "how to teach?" In the Portuguese case, answering to the first question, we may identify the development of linguistic awareness and the construction of explicit knowledge about the language, in order to form linguistically and discursively competent citizens, using language proficiently in oral formal and public contexts, in reading and in writing. Through an overview of the curricular guidelines, as well as other official documents, the answer to the second question points at what is taught about grammar in the Portuguese curriculum. Finally, since it is one of the grammar teaching approaches with more empirical research, the Grammar Lab is presented as being a good practice.
\end{abstract}

Keywords: Portuguese curriculum, grammar teaching, discovery-learning, Grammar Lab, L1-Education

Resumo: Ainda que alguns estudos evidenciem uma clivagem entre as práticas e as orientações curriculares para o ensino da língua materna, no currículo português houve sempre algum espaço para o ensino da gramática. O debate foca-se em torno das questões “para quê ensinar gramática?", “o que ensinar?" e "como ensinar?". No caso português, em resposta à primeira questão, destaca-se o desenvolvimento da consciência linguística e a construção de conhecimento explícito sobre a língua, de modo a formar cidadãos linguística e discursivamente competentes nos usos de língua, em contextos de oral formal e público, na leitura e na escrita. Através de uma visão panorâmica dos documentos curriculares, bem como de outros documentos oficiais, em resposta à segunda questão, explicitou-se o que se ensina sobre gramática no currículo português. Finalmente, por ser uma das abordagens de ensino da gramática com mais investigação empírica, apresenta-se o Laboratório Gramatical como uma boa prática.

Palavras-chave: currículo português, ensino da gramática, aprendizagem pela descoberta, laboratório gramatical, ensino da língua materna

Resumen: Aunque algunos estudios evidencian una brecha entre las prácticas y las directrices curriculares para la enseñanza de la lengua materna, en el currículo portugués siempre hubo algún espacio para la enseñanza de la gramática. El debate se centra en 
las cuestiones "¿Para qué enseñar gramática?", "¿Qué enseñar?" y "¿Cómo enseñar?". En el caso portugués, en respuesta a la primera cuestión, surge el desarrollo de la conciencia lingüística y del conocimiento explícito de la lengua, para formar ciudadanos competentes lingüística y discursivamente en el uso de la lengua en contextos orales formales y públicos, en la lectura y en la escritura. Tras una visión general de los documentos curriculares, en respuesta a la segunda pregunta, se explicó lo que se enseña sobre la gramática en el currículo portugués. Finalmente, por ser uno de los enfoques de enseñanza de la gramática con más investigación empírica, se presenta el Laboratorio Gramatical como una buena práctica.

Palabras clave: currículo portugués, enseñanza de la gramática, aprendizaje por descubrimiento, laboratorio gramatical, enseñanza de la lengua materna

Resum: Tot i que alguns estudis evidencien una bretxa entre les pràctiques $\mathrm{i}$ les directrius curriculars per a l'ensenyament de la llengua materna, en el currículum portuguès sempre hi ha hagut espai per a l'ensenyament de la gramàtica. El debat se centra en les qüestions "Per què ensenyar gramàtica?", "Què ensenyar?" i "Com ensenyar?". En el cas portuguès, en resposta a la primera qüestió, sorgeix el desenvolupament de la consciència lingüística i del coneixement explícit de la llengua, per formar ciutadans competents lingüística i discursivament en l'ús de la llengua en contextos orals formals i públics, en la lectura i en l'escriptura. Després d'una visió general dels documents curriculars, en resposta a la segona pregunta, explicarem el que s'ensenya sobre la gramàtica en currículum portuguès. Finalment, per ser un dels enfocaments d'ensenyament de la gramàtica amb més investigació empírica, presentem el Laboratori Gramatical com una bona pràctica.

Paraules clau: currículum portuguès, ensenyament de la gramàtica, aprenentatge per descobriment, laboratori gramatical, ensenyament de la llengua materna

Résumé: Bien que certaines études montrent un fossé entre les pratiques curriculaires et les directives pour l'enseignement de la langue maternelle, le curriculum portugais a toujours laissé une place à l'enseignement de la grammaire. Le débat se concentre sur les questions "Pourquoi enseigner la grammaire?", "Quoi enseigner?" et "Comment enseigner?" Dans le cas portugais, en réponse à la première question, le développement de la conscience linguistique et de la connaissance explicite de la langue se pose afin de former des citoyens compétents sur le plan linguistique et discursif à l'utilisation de la langue dans des contextes oraux formels et publics, en lecture et en écriture. Après un aperçu des documents du programme, en réponse à la deuxième question, on explique quel conetnu de grammaire est enseigné dans le programme portugais. Enfin, comme il s'agit d'une des approches de l'enseignement de la grammaire avec davantage de recherches empiriques, le Laboratoire de Grammaire est présenté comme une bonne pratique.

Mots-clés: curriculum portugais, enseignement de la grammaire, apprentissage par découverte, laboratoire de grammaire, enseignement de la langue maternelle 


\section{Introduction}

It is widely accepted that grammar teaching ${ }^{i}$ is a specific area in the didactics of Portuguese as a first language. While it is true that upon entry into compulsory schooling, children possess linguistic abilities with which they can communicate in familiar contexts, one of the specificities of Portuguese as a subject is unquestionably to provide all students with the necessary skills to consciously, intentionally and consistently master the language and its uses.

However, studies that focus on the state of grammar teaching in schools, from the perspective of students and teachers, show disheartening results (Delgado-Martins, Duarte, Miranda \& Barbeiro, 1987; Castro, 1995, 2000; Lobo, 2001, 2002; Sim-Sim \& Rodrigues, 2006; Ucha, 2007; Costa, 2007; Duarte \& Rodrigues, 2008; Silva, 2010; Ferreira, 2014). In response to this situation, educational research has reacted with not only debates on the purposes, the essential learning outcomes to be achieved and the methodology, but also the development of guidelines and classroom-based research.

In this article, the following topics will be addressed: firstly, the most relevant questions raised by the debates on grammar teaching in Portugal; secondly, the guidelines and resources for grammar teaching that is scientifically grounded and adapted to pedagogical purposes; thirdly, the grammar laboratory ('Grammar Lab') as one of the didactic strategies to teach grammar as a reflective activity. Focus is given to this approach due to the growing number of classroom-based studies that have taken the Grammar Lab as their object of research.

The most relevant questions from the debates on grammar teaching fall into three categories: Why? What? How?

The first big question has led to several studies that stress not only the reasons why it makes sense to learn grammar (why teach grammar?), but also the purposes of that learning (for what purpose should we teach grammar?).

Language learning in schools is a systematic, intentional and strategically oriented action. Grammar is taught to bolster greater linguistic awareness, based on activities of reflection and manipulation, as well as to consolidate explicit knowledge of the language and ground critical and constructive discursive action (Delgado-Martins \& Duarte, 1993, p. 15).

Linguistic awareness is defined as the stage when speakers show some capacity for detachment, reflection and systematization regarding language, revealing an awareness of the structures in communicative activities, without recourse to metalinguistic explicitness. It is an intermediate stage between intuitive knowledge and explicit knowledge of the language (Costa, 2008). 
Explicit knowledge of the language involves the teaching-learning process carried out in a school environment, "under a scientifically-based and pedagogically suitable proposal from the teacher, in which students acquire explicit knowledge of how the language is structured and operates (...)" (Delgado-Martins \& Duarte, 1993, p.15) ${ }^{\text {ii }}$. It is fundamental to understand this process based on the distinction between language acquisition and language learning. The process of acquisition is generally ensured, since "the child knows the sounds of his/her language and its rules of combination, regular inflectional paradigms, productive rules of word formation, general patterns of simple sentences, coordinates and the many types of subordinates, and the more complex mechanisms of giving meaning, the combinations of words, the forms of different types of linguistic acts in interpretative situations in which he/she usually participates, in addition to having an appreciable lexical background." (Delgado-Martins \& Duarte, 1993, pp. 11-12). The development of grammatical knowledge is, therefore, related to learning the language the child implicitly knows. What instruction/the school does is highlight the passage from a spontaneous use of the language to the possibility of a deliberate, conscious and analytical use.

In addition to these learning outcomes, students also learn language dimensions that, not having been the object of spontaneous acquisition, emerge from social interaction, from discursive plurality and from the performance of communicative competences. Linguistic diversity (variants and varieties of language), the organization of texts in terms of textual genres, the lexicon, and writing conventions are examples of learning outcomes that the school enables and develops in students, making them more apt in formal communicative contexts.

Critical and constructive discursive performance encompasses fundamental learning outcomes not only for the comprehension and expression of formal and public genres of speaking, writing and reading, but also for the development of a critical attitude regarding the social uses of language.

In Portugal, the answer to the question regarding the purpose of teaching-learning grammar, which gathers considerable consensus in official documents and among researchers and trainers, is therefore three-layered: to develop linguistic awareness, to build explicit knowledge about language (metalinguistic knowledge) and to be a linguistically and discursively competent citizen in the uses of the language, in formal and public oral contexts, as well as reading and writing.

The second problem (What to teach?) raises questions on at least two levels: on the one hand, the decision regarding which perspective to follow - normative or descriptive; on the 
other, the sequencing of the learning outcomes to be achieved at each level of education throughout compulsory schooling.

The twelve years of compulsory schooling constitute a period of essential learning for life. Therefore, in the teaching of grammar, as in other areas of knowledge, the teacher must develop a descriptive and explanatory, but also normative attitude. It is up to the teachers to reconcile these two perspectives, in their teaching practice, in terms of what they are teaching and why they are teaching.

What the object of teaching-learning should be and at what stage of the school trajectory should it be taught/learned are issues that are of interest to curriculum decision-makers, as well as to teachers when they have to decide how to advance learning in the classroom, for example. It thus becomes essential to conduct research in at least two fields: research on language development and research on grammar didactics.

To make these decisions, research in the field of language acquisition and development is crucial, providing insights into the development of structures in a given language that can be extremely useful for phasing grammatical contents for learning. Considering that certain grammatical constructions will be acquired later, due to their degree of complexity, the role of the school is to expose students to formal teaching situations to stimulate more consistent learning, but it is also important to use information from psycholinguistics on the complexity of processing certain structures for the phasing of grammatical contents in the mother tongue subject (Costa, 1999). Also relevant are classroom-based research studies that contribute to gaining insights into the most effective teaching processes in learning in areas where one cannot rely on implicit knowledge.

In Portugal, throughout compulsory schooling, the grammar curriculum advocates as essential learning outcomes the development of linguistic awareness and explicit knowledge of the language in the phonological, morphological, syntactic, lexical, semantic, textual and discursive planes, as well as of word classes (DGE-ME, 2018). It is an approach to language that assumes a descriptive and explanatory perspective, but without neglecting the normative perspective as well, in activities at two levels: language learning as an autonomous dimension of knowledge and contextualized language learning, through use of grammatical knowledge for comprehension and oral and written expression.

The third question (How to teach?) confronts us with models, methods and teaching resources. There is no classroom-based research that could serve to systematically describe the procedures used by teachers to teach grammar. There are, however, indicators (data available 
on practices, guidelines and reflection motivated by changes to the curriculum in the last few decades) that show the coexistence of two models of grammar teaching:

- a predominantly transmission model, built on knowledge transmitted by the teacher to students who then have to practice and are tested on what they have learned;

- a model of knowledge built by students from teaching-learning situations the teacher has strategically planned.

Within the transmission model, teaching is based on normative rules and its main strategy is memorization or knowledge of definitions. The grammatical contents are all understood as declarative and knowing grammar is about knowing a set of definitions and terms that, supposedly, support a good command of the language. Grammar didactics restricted to this method has negative consequences, such as incipient knowledge, rejection regarding knowledge about the language, and poor performances in reading, writing and formal oral genres. In this regard, Castro (2000, p. 149) states: "In fact, when we examine the available materials, the impression with which we are most often left is that grammar teaching methodology seems to have been relatively immune to changes that have affected the teaching of other contents - whether due to a high degree of formalization, or an eminently external perspective of the reader/student regarding the object/language, implying the suppression of the learners' prior knowledge (in fact, the instrumentality that supposedly characterizes grammatical knowledge is often no more than a rhetorical device)."

Grammar understood as knowledge built by the students opened different practical approaches to grammar teaching, from the end of the 1970s:

a) The teaching of grammar 'in context' ${ }^{\text {'iii }}$ is understood as an non-conscious linguistic activity or reflective practice associated to the interpretation of communicative acts without the use of metalanguage, or "reflective but unconscious practice devoid of formal categories (or only the most elementary ones of common language, such as 'word', 'name', 'sentence', 'meaning', etc.), which is the very essence of negotiating meaning inherent to communicative acts, a practice known as epilinguistic activity." This is part of a conception of mother tongue teaching as a pedagogy of discourses (J. Fonseca \& F. I. Fonseca, 1977/1990; F. I. Fonseca 1994, 2000b; J. Fonseca 1986, 1988-89). For example, an analysis of the unit 'sentence' is seen not as a decontextualized grammatical construction, but rather as embedded in text/discourse.

b) The educational approaches to grammar teaching built on the basis of the principles of discovery-learning, with activities and modes of questioning based on data given by the teacher or gathered by the students (Duarte, 1992, 1998; Prista, 1992; Brito, 1997, 1998). 
Within these pathways of discovery-learning, we highlight the Grammar Lab, which is one of the approaches to "language awareness" focused on autonomous grammar teaching. This grammar teaching method (which will be explained in more detail in the third section of this article) takes into account, first, the implicit linguistic knowledge with which students arrive at school and, secondly, the scientific method of building knowledge.

\section{Guidelines and resources}

At the same time that the Portuguese syllabi for compulsory schooling have been subject to change in the last few decades (Rodrigues 2017), scientific studies on educational linguistics and didactics of Portuguese have contributed with data relevant to more consistent and informed grammar teaching.

Grammar teaching also has a unified linguistic terminology for basic and secondary education, which ensures metalinguistic reflection will be developed with consistency throughout the entire school career. After a long process of elaboration, public consultation, review and monitored experimentation, Portuguese teachers count on a Terminological Dictionary online (http://dt.dge.mec.pt/), the responsibility of the Directorate-General of Education, Ministry of Education. This dictionary incorporates relatively consensual conceptual information in the scientific community formulated in view of the pedagogical purpose of this resource, available to teachers and teaching agents.

Other documents of high educational potential were produced in recent decades by the Ministry of Education. Although they are not prescriptive documents, they are a mandatory reference in grammar teaching, for example: Sim-Sim, Duarte \& Ferraz (1997), Freitas, Alves \& Costa (2007), Duarte (2008), Gonçalves, Guerreiro \& Freitas (2011). These documents put forward proposals for grammar teaching activities, one of which is the Grammar Lab.

\section{How to teach grammar: the Grammar Lab as a good practice}

As a response to the challenge of teaching grammar as a process of raising linguistic awareness, in the late 1990s, Inês Duarte published an article entitled "Grammar Lab: contexts of compulsory use of subjunctive" (Duarte, 1992). Six years later, the author underpinned this didactic proposal by defining "some good reasons for grammar teaching" (Duarte, 1998) in a paper in which she clearly rejects the communicative approach, known as "language functioning - analysis and reflection", in the Portuguese syllabi in force at the time (DGEBS, 1991). As the author claims, in those Portuguese syllabi, grammar reflection was remaining at the "curriculum periphery" (Duarte, 1991). There was no place for autonomous classroom activities on grammar 
since all grammar description would rise from the improvement of language uses in communicative contexts of listening, speaking, reading and writing. Grammar Lab was meant to break with the communicative syllabi, where formal reflection about language occupied a secondary place.

In addition, the perspective underpinned by the Grammar Lab approach was an innovative way to develop grammar reflection at school, very different from the transmission model, in which only a prescriptive view about language was allowed. The traditional approach for grammar teaching in Portugal disappeared from the official documents since the early eighties. However, classroom practices kept a very traditional view on grammar, not only about its object - standard Portuguese - but also about the way of teaching it, through definitions and terms that are frequently inadequate to linguistic description. As a reaction to this conception of grammar teaching, many teachers were taking the pathway of a straight communicative perspective, with grammar being subordinated to language uses (Costa, 2010; Lobo, 2001, 2002). The place of grammar in the curricula was considered to be at risk (Duarte, 1991, 1992, 1993).

Facing grammar teaching's vulnerability, as it has been referred before, Duarte (1998) proposes a set of "good reasons for grammar teaching", including:

- Instrumental reasons

- Attitudinal-axiological reasons

- Cognitive and metacognitive reasons

Referring to the instrumental reasons, Duarte (1998, pp. 110-123; 2008, pp. 9-16) notes that research on linguistic awareness has brought into light grammar learning positive effects on reading and writing skills. Within the set of instrumental reasons, the author points out the access to standard Portuguese by all children. The explicit knowledge of the standard variety of the mother tongue is seen as a condition to become a proficient speaker, reader, and writer. Nevertheless, aiming that all children master the standard Portuguese does not mean to eradicate linguistic diversity from the curricula. On the contrary, linguistic variation is considered an essential content for grammar reflection.

A second good reason to explicitly study grammar is the development of late acquisition structures. When children arrive at school, by the age of six, they do not master all kinds of discourse registers, neither all the linguistic structures from their mother tongue. Some less frequent structures, almost only used in formal registers, need school contexts to emerge. School discourses enhance linguistic resources, enabled to be used, progressively, in even more complex discourse interactions. This leads us to the third reason for explicit grammar learning: 
the development of oral language. Becoming aware of language functioning underpins the skills that improve and diversify language uses. Each child, as a future citizen, must be empowered to master different kinds of oral and written registers, which requires active participation in the community discourses.

Lastly, another instrumental reason is that studying involves a special kind of effort to understand, to remember and to use knowledge, which is achieved through one's own language as a mean to access information. In this sense, since grammar learning improves language oral and written skills, it is also a pre-condition to academic success in all subjects and knowledge areas. Furthermore, the explicit reflection about one's mother tongue, being able to describe and explain it, is an advantage whenever we need to learn a foreign idiom. In the latest versions of "focus on form" second language learning, literature advocates ${ }^{\text {iv }}$ the pedagogical importance of the explicit knowledge of forms and functions.

The expression "attitudinal-axiological reasons" refers to a subset of goals to teach grammar that allow the development of attitudinal and citizenship skills. As it was mentioned above, the main object of grammar reflection is standard Portuguese, which is one of the linguistic varieties that children study at school. When a child enters school, he/she has linguistic intuitions about his/her mother tongue. This implicit knowledge hardly corresponds to the standard variety of the language. The implicit grammar that children bring to the classroom is the grammar of an oral, informal variety, a dialect or a national variety, different from the official school language ${ }^{v}$. This set of spontaneous knowledge must be considered the starting point to build knowledge about language. It is, then, important to recognize in the classroom that all varieties are equal in having complex and structured rules. By comparing linguistic uses in real contexts and becoming aware of similarities and differences, children may achieve the explicit knowledge of standard Portuguese, and simultaneously develop self-confidence in their own language uses, thus mastering different registers. Moreover, becoming aware of individual, social and geographic differences of linguistic varieties, free from prejudices, promotes cultural interest, and reinforces attitudes of tolerance towards language and people differences.

Finally, a subset of good reasons for grammar teaching enhances cognitive and metacognitive goals. Those goals are transversal skills that may be considered as a crux of the matter to a grammar teaching approach of the kind of a Grammar Lab. To learn about our own language, by transforming a spontaneous knowledge into a reflective knowledge, is a unique intellectual experience. In the words of Costa (2007), to learn about the grammar of our language 
is a humanistic knowledge that must be experienced through academic development. In a particular way, when grammar is taught as a reflective activity, it provides the development of cognitive and metacognitive skills, as an exercise of analytical thinking, and may be a way of learning the steps of the scientific method, which is required by any science.

Almost thirty years after the first Grammar Lab was published, we may underline that its pedagogical strength subsists in promoting grammar reflection while enhancing critical reasoning.

As a teaching sequence, a Grammar Lab has four main stages (Costa \& Santos, 1999; Costa, Cabral, Santiago \& Viegas, 2011; Duarte, 1992), as represented in figure 1.

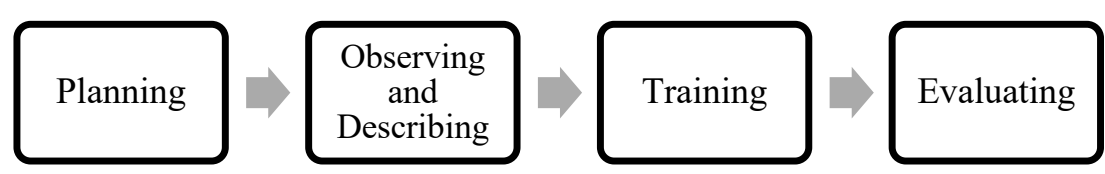

Figure 1. Grammar Lab as a teaching sequence

At the first stage, all the work of preparing the data to be observed stays in the teacher's hands. She/he needs to know what linguistic unity or process is meant to be described (i.e., explicitly learned). Then, the teacher has to organize the linguistic data in meaningful paradigms, in order to scaffold the observation and the discovery of regularities, which will lead to the properties to be described (and explicitly learned). By something "explicitly learned" we are referring to grammar content that the children became able to refer to with metalanguage. In other words, students "explicitly know" grammar when they are referring to and explaining language through language. The capacity to use, progressively, proper metalanguage should be developed during the school years, and Grammar Lab for young children may rely more on their intuitions than in lists of terms and concepts.

An example of an organized paradigm to make children aware of the agreement between the subject and the predicate (as a relevant property of such a syntactic function) was retrieved from a Grammar Lab for primary school by Costa \& Santos (1999, p. 299).

1. Which of these sentences is correct?

$O$ Joãosaltou o muro.

The João jumped ${ }_{\text {[sg.] }}$ the wall.

'John jumped the wall.'

Os meninos saltou o muro. 
The children jumped ${ }_{[\mathrm{sg} .]}$ the wall.

'The children jumped the wall.'

Chegou a casa os meninos todos.

Arrived ${ }_{[s g .]} \quad$ the home the children all.

'All the children arrived home.'

Chegaram a casa os meninos todos.

Arrived ${ }_{\text {[pl.] }}$ the home the children all.

'All the children arrived home.'

In this example, the data to be observed are minimal pairs of sentences that children should judge based on their intuitions on subject-verb agreement. Data, in this case, consisted of sentences build on purpose to the exercise. Still, the teacher may collect data from very different sources for a Grammar Lab: oral and written texts, the student's written productions, etc.

Once the data are organized (are sufficient and relevant) to find regularities and build generalizations, the teacher only needs to count on children's implicit knowledge, since "most of the data needed for a grammar lesson are already in the children's heads, so the teacher's role is mainly to guide them in exploring the patterns in the data and in gradually expanding their linguistic horizons" (Hudson, 1992, p. 10).

The next stage, known as "observing", in Fig. 2, is the heart of the Grammar Lab as a learning sequence, in which the students' discovery-learning pathway is guided by questioning in the style of Bruner's (Hudson, 1992, pp. 8-14). At this stage, Duarte $(1992,2008)$ proposes five steps that guide students' reasoning in a scientific way, by learning how to formulate questions, to observe patterns, to raise hypotheses (formulating rules that need to be verified), to test those hypotheses through the manipulation of new data in the same conditions, and to validate the hypotheses (confirming or infirming them, generalizing the achieved rules). 


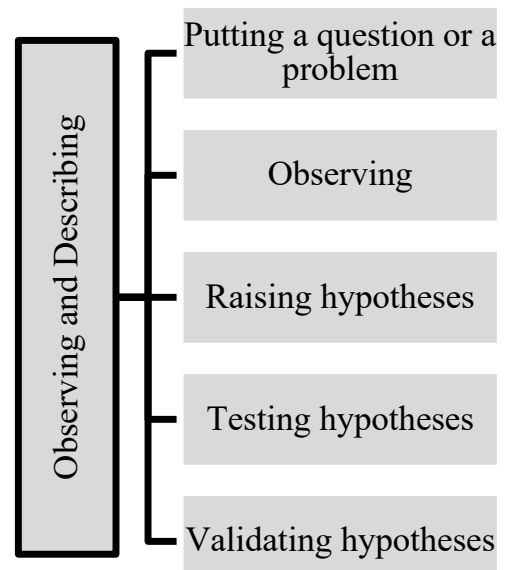

Figure 2. Steps for scientific reasoning in a Grammar Lab

In this discovery-learning approach, while studying grammar, students are asked to reflect with some degree of autonomy over language properties, starting from its intuitive knowledge and their own language use. Some examples from the sequence "observing and describing" were taken from a Grammar Lab on adversative and concessive sentences, implemented with ninth graders (Costa, 2010). The repetition of the connective word mas ('but') in most of the students' opinion texts was the initial problem: how to express contrastive ideas avoiding the repetitions of mas? Young writers analyzed their own use of contrastive connectives in arguments and counterarguments. In this case, the previous data to be observed were students' own texts in the prewriting versions. Afterwards, sentences which were built over the students' sentences were used. In Figure 3, there is an example of the step “observing”. Students had to find out the differences between two connective words mas ('but') and embora ('although') and the verb mood (indicative and subjunctive mood).

2. Observa e compara as frases (1) e (2).

(1) As descobertas científicas são importantes, mas algumas dependem do sofrimento de animais.

(2) As descobertas científicas são importantes, embora algumas dependam do sofrimento de animais.

2.1. Identifica duas diferenças.

A primeira diferença é

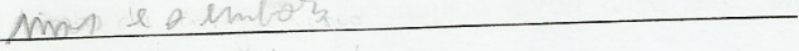

e a segunda diferença é

Figure 3. Step "Observing" 
As we have noted before, metalanguage is used only as a facilitator tool, whenever it is needed. At this stage, in the student's answer, no metalinguistic term is used: the student shows awareness of the property to be described without classifying it. Only by the end of the Grammar Lab, after the manipulation of linguistic material and the understanding of its functioning, terms and classifications were demanded.

In Figure 4, there is an example of the "raising a hypothesis" step, formulated as a multiple-choice item, to guide the students learning pathway.

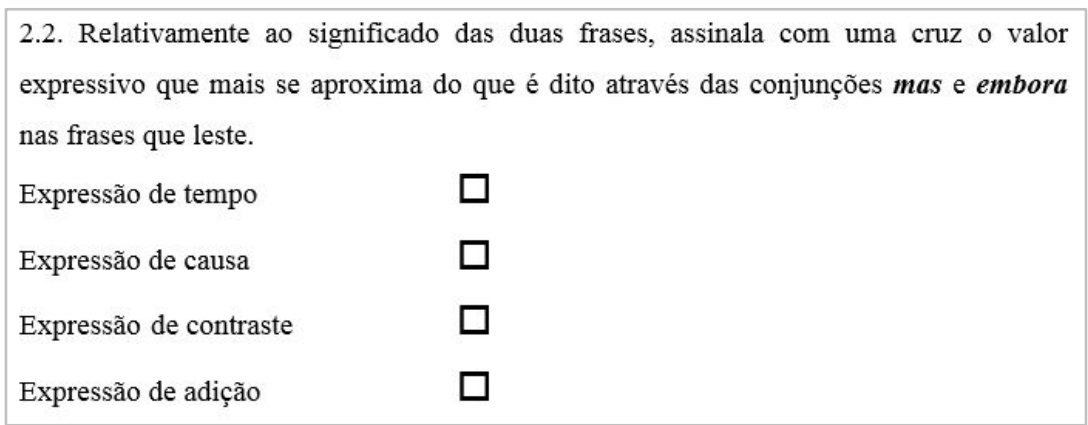

Figure 4. Step "Raising a hypothesis"

Based on their intuitions, students had to choose the semantic value of the connective words, which allowed them to discover the possibility of commutation between an adversative connective and a factual concessive one.

The next steps, "testing" and "validating" the hypothesis through the manipulation of new data was granted by some sentence-combining exercises. This new step allowed the extension of the linguistic horizons since students had to build more sentences by using unusual connectives words with the same semantic value, but with different distributional properties.

After the discovery of some properties of language functioning (in the example, the main characteristics of adversative and concessive sentences), a Grammar Lab should always provide for a training stage, to consolidate the knowledge previously made explicit. This training may be done through grammar exercises or by transferring grammatical knowledge into reading, writing or oral tasks. The evaluation, as well, should be guided by formative principles. Declarative knowledge, involving classification and uses of terms (for instance, "conjunction", "adversative/concessive sentence", "subjunctive mood"), may be tested. However, procedural knowledge (for instance, in using different connectives in written and oral texts) should be the aim of the pedagogical evaluation in a Grammar Lab. 
Research on Grammar Lab as a classroom activity, in the last decades, stresses the benefits of its articulation with writing and reading development (Batalha, 2018; Costa, 2010, a.o.). In particular, Silvano \& Rodrigues (2010) claim that Grammar Lab positive effects in language use crucially depend on its discourse contextualization, in meaningful writing and reading activities in the classroom. Differently from decontextualized grammar exercises, a Grammar Lab should be integrated into meaningful discourse participation, in classroom projects.

\section{Final remarks}

In this article, we attempted to make a state of the art on the grammar teaching debate in Portugal. Unlike other educational systems (Myhill \& Watson, 2014), the discussion about whether to teach or not to teach (explicitly) grammar was quickly overcome, in the nineties, by the questions "why", "what" and "how to teach grammar". The metaphor of "grammar wars" (idem, p. 1) does not apply to the history of Portuguese grammar teaching, where the value of grammar has been recognized, in research as well as in the Portuguese curricula, as a crux of the matter for first language education.

Different answers, however, have been given to the "why", "what" and "how", and the debate is still undergoing. Portuguese syllabi and other curricular documents of the last twenty years have been adopting a framework in which grammar teaching is seen as a pathway from implicit to explicit knowledge, underpinning the capacity to use verbal language to refer to and to explain language. From this perspective, as it was explained above, grammar teaching matters in order to develop language awareness, as well as to build metalinguistic knowledge. Those capacities are not seen as isolated skills. The capacity to manipulate and control linguistic resources is at the heart of an active and critical discourse participation. In other words, while grammar has an autonomous place as a curricular content, the goals of grammar teaching and learning are achieved through the participation in meaningful discourse contexts, including problem-solving contexts where grammar reflection is at stake. In particular, considering the most recent learning outcomes (DGE-ME, 2018), by the end of primary school, grammar competence is conceived as a:

"progressive appropriation of the awareness and knowledge of unities, structures, rules and language uses, gradually developing the capacity to reflect on language and use specific language to refer to language knowledge itself." (4th grade, p. 4).

In the same Essential Learning for Portuguese (DGE-ME 2018), we may also read that: 
Portuguese classes must be oriented towards the development of a (...) "Grammar competence through a gradual and systematized knowledge about basic aspects from different domains (phonological, morphological, word classes, syntactic, semantic, and textual-discursive domain)" (DGE 2018, p. 3).

This conceptualization of grammar teaching, placed in a consensual field of ideas from the intended curricula, as well as from didactic research, faces a main challenge: the divide between theories and practices. In Portugal, as in other countries, there is still a long way to go before grammar teaching, as a part of the education for reflective and critical citizens, moves from the utopic place in the curricular guidelines to the topic of teacher's action, in the classroom.

\section{References}

Batalha, J. (2018). Relações entre conhecimento explícito da língua e a competência de leitura. (Doctoral dissertation). Retrieved from Faculdade de Ciências Sociais e Humanas da Universidade Nova de Lisboa. http://hdl.handle.net/10362/43439

Brito, A. M. (1997). Retomar e reinventar o ensino da gramática da Língua Materna. In Associação de Professores de Português, Atas do $2{ }^{\circ}$ Encontro Nacional da Associação de Professores de Português (pp. 54-64). Porto: Areal Editores.

Brito, A. M. (1998). Que gramáticas ensinar? A língua materna e a paixão de aprender. 2. ${ }^{\circ}$ Encontro de Professores de Português. Homenagem a Eugénio de Andrade (pp. 255261). Porto: Areal Editores.

Castro, R. V. (1995). Para a análise do discurso pedagógico. Constituição e transmissão da gramática escolar. Braga: Universidade do Minho.

Castro, R. V. (2000). De quem é esta gramática? Acerca do conhecimento gramatical escolar. In C. Reis (Ed.). Didáctica da língua e da literatura (Vol. 1, pp. 141 - 151). Coimbra: Almedina.

Costa, A. (2010). Estruturas contrastivas: desenvolvimento do conhecimento explícito e da competência de escrita (Doctoral dissertation). Retrieved from University of Lisbon. http://hdl.handle.net/10451/2216

Costa, M. A. (1999). Incidências da investigação psicolinguística na didática da língua portuguesa. In C. Mello (Ed.), I Jornadas científico-pedagógicas de Português (pp. 91-112). Coimbra: Almedina.

Costa, J. (2007). Conhecimento gramatical à saída do ensino secundário: estado actual e consequências na relação com leitura, escrita e oralidade. In C. Reis (Ed.) Actas do Congresso 
Internacional sobre o Ensino do Português (pp. 149-165). Lisboa: Ministério da Educação-Direção-Geral da Inovação e Desenvolvimento Curricular.

Costa, J. (2008). Estudar gramática: (des)interesse e (in)utilidade. Revista do Externato Cooperativo da Benedita, 23-29.

Costa, J., Cabral, A. C., Santiago, A., \& Viegas, F. (2011). Guião de implementação do Programa de Português do ensino básico - Conhecimento explícito da língua. Lisboa: Ministério da Educação- Direção-Geral da Inovação e Desenvolvimento Curricular.

Coutinho, M. A, Tanto, C., \& Luís, R. (2015). O conhecimento explícito dos textos e da língua. In E. Leurquin, M. A. Coutinho \& F. Miranda (Eds.), Formação docente. Textos, teorias e práticas (pp. 133-164). Campinas, SP: Mercado de Letras.

Delgado-Martins, M. R., Duarte, I., Miranda, A. J., \& Barbeiro, L. F. (1987). Para uma caracterização do saber linguístico à entrada no ensino superior. Lisboa: Associação Portuguesa de Linguística.

Delgado-Martins, M. R., \& Duarte, I. (1993). Brincar com a linguagem, conhecer a língua, fazer gramática. In M. F. Sequeira (Ed.), Linguagem e desenvolvimento (pp. 9-16). Braga: Universidade do Minho.

DGE-ME (2008). Dicionário terminológico em linha. Retrieved from DGE http://dt.dge.mec.pt/

DGE-ME (2018). Aprendizagens Essenciais. Lisboa: Direção-Geral da Educação. Retrieved from DGE http://www.dge.mec.pt/aprendizagens-essenciais-0

DGEBS (1991). Programa de Língua Portuguesa - Plano de Organização do Ensino/Aprendizagem - Ensino Básico - 3. ${ }^{\circ}$ Ciclo, vol. I e II. Lisboa: Ministério da Educação-Direção-Geral dos Ensinos Básico e Secundário.

Duarte, I. (1991). Funcionamento da língua: a periferia dos NPP. In M. R. Delgado-Martins et al., Documentos do Encontro sobre os Novos Programas de Português (pp. 45-59). Lisboa: Colibri.

Duarte, I. (1992). Oficina gramatical: contextos de uso obrigatório de conjuntivo. In M. R. Delgado-Martins, D. Pereira, A. I. Mata, M. A. Costa, L. Prista, \& I. Duarte, Para a didáctica do Português. Seis estudos de Linguística (pp. 165-177). Lisboa: Edições Colibri.

Duarte, I. (1993). O ensino da gramática como explicitação do conhecimento linguístico. In L. F. Barbeiro, E. Fonseca, C. Nobre \& E. Machado (Eds.), Ensino-aprendizagem da língua 
portuguesa (pp. 49-60). Leiria: Escola Superior de Educação-Instituto Politécnico de Leiria.

Duarte, I. (1998). Algumas boas razões para ensinar gramática. A língua materna e a paixão de aprender. $2{ }^{\circ}$ Encontro de Professores de Português. Homenagem a Eugénio de Andrade (pp. 110-123). Porto: Areal.

Duarte, I. (2008). O conhecimento da língua: desenvolver a consciência linguística (pp. 4960). Lisboa: Ministério da Educação-Direção-Geral de Inovação e de Desenvolvimento Curricular.

Duarte, R., \& Rodrigues, S. V. (Ed.) (2008). Dificuldades dos alunos em Língua Portuguesa. Lisboa: Ministério da Educação-Direção-Geral de Inovação e de Desenvolvimento Curricular.

Ellis, R. (2008). Explicit Form-Focused instruction and second language acquisition. In B. Spolsky \& F. M. Hult (eds.), The handbook of educational linguistics (pp. 437-455). Oxford: Wiley-Blackwell.

Ferreira, P. (2012). Conceções e práticas dos professores de Língua Portuguesa em relação ao ensino e à aprendizagem da gramática: um estudo exploratório no $2{ }^{\circ}$ Ciclo do ensino básico (Doctoral dissertation). Retrieved from Escola Superior de Educação de Lisboa http://hdl.handle.net/10400.21/2321

Ferreira, P. (2014). Conhecimento gramatical e conceções de futuros professores relativamente ao ensino e à aprendizagem da gramática. Tejuelo Monografico, 10, 27-48.

DOI: $10.17398 / 1988-8430$

Fonseca, F. I. (1994). Gramática e Pragmática: estudos de Linguística Geral e de Linguística Aplicada ao ensino do Português. Porto: Porto Editora.

Fonseca, F. I. (2000). Da Linguística ao ensino do Português. In Neusa Bastos (Org.), Língua Portuguesa: teoria e método (pp. 11 - 28). São Paulo: Editora da PUC-SP.

Fonseca, F. I., \& Fonseca, J. (1977/1990). Pragmática linguística e ensino do Português. Coimbra: Almedina.

Fonseca, J. (1986). A frase no texto. Algumas propostas de trabalho para a aula de língua materna. Palavras, 9, 11-14. Lisboa: Associação de Professores de Português.

Fonseca, J. (1988-89). Ensino da língua materna como pedagogia dos discursos. Diacrítica, 34, 63-77. Braga: Universidade do Minho. 
Freitas, M. J.; Alves, D., \& Costa, T. (2007). O conhecimento da língua: desenvolver a consciência fonológica. Lisboa: Ministério da Educação-Direção-Geral de Inovação e de Desenvolvimento Curricular.

Gonçalves, F., Guerreiro, P., \& Freitas, M. J. (2011). O conhecimento da língua: percursos de desenvolvimento. Lisboa: Ministério da Educação-Direção-Geral de Inovação e de Desenvolvimento Curricular.

Hudson, R. (1992). Teaching grammar. A guide for the national curriculum. Oxford: Blackwell.

Lobo, A. (Ed.) (2001). O ensino e a aprendizagem do Português na transição do milénio. Relatório preliminar - Documento de trabalho. Lisboa: Associação de Professores de Português.

Lobo, A. (Ed.) (2002). O ensino e a aprendizagem do Português na transição do milénio. Relatório final do projecto «Português 2002». Lisboa: Associação de Professores de Português.

Lopes, A. C. M. (2005). O “conhecimento sobre a língua”: algumas reflexões. In M. L. Dionísio \& R. V. Castro, O Português nas escolas. Ensaios sobre a língua e a literatura no ensino secundário (pp. 147 - 158). Coimbra: Almedina.

Lopes, A. C. M. (2006). O “conhecimento para a língua" no ensino do Português. In I. Duarte e P. Morão (orgs), Ensino do Português para o século XXI (pp. 75-82). Lisboa: Edições Colibri/Departamento de Linguística Geral e Românica e Departamento de Literaturas Românicas/Faculdade de Letras da Universidade de Lisboa.

Myhill, D. A., \& Watson, A. (2014). The role of grammar in the writing curriculum: A review. Journal of Child Language Teaching and Therapy, 30 (1), 41-62. https://doi.org/10.1177/0265659013514070

Prista, L. (1992). Oito fichas de gramática. In M. R. Delgado-Martins, D. Pereira, A. I. Mata, M. A. Costa, L. Prista, \& I. Duarte, Para a didáctica do Português. Seis estudos de Linguística (pp. 119-163). Lisboa: Edições Colibri.

Rodrigues, S. V. (2017). O ensino do Português nas primeiras décadas do século XXI. In Conselho Nacional de Educação, Lei de Bases do Sistema Educativo: balanço e prospetiva (Vol. I, pp. 247-291). Lisboa: Conselho Nacional de Educação.

Santos, A. L., \& Costa, A. L. (1999). Grammar in the portuguese national curricula: What do we want to teach and why? In J. Sarkissian, Proceedings of the Twenty-second Annual 
Conference on the Teaching of Foreign Languages and Literatures (pp. 289-316). Youngstown State University.

Silva, M. C. V. (2010). Para uma didáctica da gramática: a aula de língua portuguesa como um laboratório de língua. XXV Encontro Nacional da Associação Portuguesa de Linguística: Selected Texts, 717-732.

Silvano, P., \& Rodrigues, S. V. (2010). A Pedagogia dos Discursos e o Laboratório Gramatical no ensino da gramática. Uma proposta de articulação. In A. M. Brito (org.), Gramática: história, teorias, aplicações (pp. 275-286). Porto: Faculdade de Letras da Universidade do Porto-Centro de Linguística da Universidade do Porto.

Sim-Sim, I., \& Rodrigues, P. (2006). O ensino da gramática visto por professores e alunos. In I. Sim-Sim (Ed.). Ler e ensinar a ler (pp. 125-138). Porto: Edições ASA.

Sim-Sim, I., Duarte, I., \& Ferraz, M. J. (1997). A língua materna na educação básica - competências nucleares e níveis de desempenho. Lisboa: Ministério da Educação-Departamento do Ensino Básico.

Ucha, L. (ed.) (2007). Desempenho dos alunos em Língua Portuguesa - ponto da situação. Lisboa: Ministério da Educação-Direção-Geral de Inovação e Desenvolvimento Curricular.

\footnotetext{
${ }^{i}$ Grammar teaching is one of the expressions commonly used to label pedagogical-didactic activities related to linguistic and metalinguistic skills: "The degree of awareness and control over linguistic knowledge determines the evolution of linguistic mastery and requires formal teaching, which has been called teaching how language works, teaching explicit knowledge or simply grammar teaching." (Sim-Sim and Rodrigues 2006, 126). In this article, we have adopted the term grammar teaching because it is the most used in the context of school practice.

ii The concept of metalinguistic competence here is not restricted to the areas of morphology and syntax, but also includes the areas of phonology, semantics, linguistic variation, texts and discourses (Lopes 2005, 2006, Coutinho, Tanto and Luís 2015).

iii This approach was assumed as compulsory in the curriculum guidelines in Portuguese syllabi approved in 1991.

iv On the focus-on-forms vs. focus-on-form debate, and the goals for explicit learning in focus-formed instruction, see, for instance, Ellis (2010).

${ }^{\vee}$ On this idea, see also Hudson (1992).
}

\begin{abstract}
Authors' information
Ana Luísa Costa is Assistant Professor at Higher Education College of the Polytechnic Institute of Setúbal (Portugal), and researcher at the University of Lisbon Linguistics Centre (CLUL). As a researcher, her work is focused in grammar teaching, writing development, academic writing, and literacies. Her Ph.D. dissertation, titled Contrast structures: the explicit knowledge of language and writing development, was defended in 2010 (University of Lisbon). She authored over forty scholarly papers and chapters, and over sixty oral presentations in different academic contexts. She participated in some research projects in the field of Linguistics, as well as in projects related to educational matters, and collaborated with different universities and with the Educational Assessment Institute of the Ministry of Education. She teaches different courses of Didactics and Linguistics in training programs for pre-school teachers and basic school teachers at the Higher Education College of the Polytechnic Institute of Setúbal, and she is coordinator of the basic education undergraduate program.
\end{abstract}

E-mail: ana.costa@ese.ips.pt 
Sónia Valente Rodrigues is Assistant Professor at Faculty of Letters of the University of Oporto (Portugal), and researcher at the University of Oporto Linguistics Centre (CLUP). As a researcher, her work is focused in didactic of Portuguese L1 and in Discourse Analysis. Her Ph.D. dissertation, titled Structure and functioning of controversial verbal interaction. Contribution to the study of polemicity in Camilo Castelo Branco, was defended in 2008 (University of Oporto). She authored scholarly papers and chapters, and oral presentations in many different academic contexts. She teaches different courses of Didactics and Linguistics in training programs for basic school and high school teachers at the Faculty of Letters of University of Oporto.

E-mail: srodrigues@letras.up.pt

To cite this article:

Costa, A. L. \& Rodrigues, S. V. (2019). Grammar teaching in Portugal. Bellaterra Journal of Teaching \& Learning Language \& Literature 12(2), 21-40. DOI: https://doi.org/10.5565/rev/jt13.809 